\title{
Classificação e propriedades químicas e físicas de Antropossolos no Município de Guarapari - ES
}

\section{Classification and chemical and physical properties of Anthropossols in the Municipality of Guarapari - ES}

\author{
Rafael Cardoso Teixeira ${ }^{*} \bowtie\left(1 D\right.$, Pablo de Azevedo Rocha ${ }^{2} \varangle$ (D), \\ André Luiz Lopes de Faria1 $₫\left(\mathbb{D}\right.$, Liovando Marciano da Costa ${ }^{1} \bowtie(0)$
}

\author{
1Departamento de Geografia Centro de Ciências Humanas, Letras e Artes, \\ Universidade Federal de Viçosa, Viçosa, MG, Brasil \\ 2Departamento de Geografia Centro de Ciências Humanas e Naturais, \\ Universidade Federal do Espírito Santo, Vitória, ES, Brasil \\ E-mail: pab_zulu@yahoo.com.br (PAR); andre@ufv.br (ALLF); liovandomc@yahoo.com.br (LMC) \\ *E-mail para correspondência: teixeirarcgeo@gmail.com
}

Recebido (Received): 05/02/2021 Aceito (Accepted): 06/10/2021

Resumo: Em ambientes urbanizados, modificados por ações antrópicas, os antropossolos tendem a se tornar parte integrante da paisagem e devem ser reconhecidos perante as suas peculiares características, pois modificam a morfologia da paisagem com a formação de novas feições. Estes solos são formados exclusivamente por ação direta das atividades humanas e são constituídos por uma ou mais camadas antrópicas, compostas de materiais orgânicos e/ou minerais possuindo espessura mínima de $40 \mathrm{~cm}$. Este trabalho tem como objetivo avaliar as propriedades químicas, físicas e a classificação morfológica de quatro perfis de antropossolos pesquisados na área urbana do município de Guarapari - Espírito Santo. Os antropossolos analisados apresentaram características heterogêneas, indicando variabilidade de materiais na formação destes. Os perfis 1, 3 e 4 apresentam descontinuidades químicas específicas entre os horizontes e camadas naturais em relação às camadas formadas pela ação antropogênica, como lixos e rejeitos de volume pedológico depositados. Quanto às características químicas e morfológicas analisadas foi possível classificar os perfis em três subordens distintas (Sômico, Decapítico e Líxico), três grandes grupos (Áquico, Camádico e Parciálico) e dois subgrupos (Alumínico e Eutrófico). Dessa forma os perfis tiveram a seguinte classificação: Antropossolo Sômico Camádico Eutrófico, Antropossolo Decapítico Parciálico Alumínico e dois Antropossolos Líxicos Áquicos Eutróficos.

Palavras-Chaves: Ambiente Antropogênico; Ação Antrópica; Descrição Morfológica.

Abstract: In urbanized environments, altered by anthropic actions, anthrosols tend to become an integrated part of the landscape and must be recognized for their peculiar characteristics, since they alter the morphology of the landscape with the formation of new features. These soils are formed exclusively by the human activities direct action and are composed by one or more anthropogenic layers, constituted by organic and/or mineral materials with a minimum thickness of $40 \mathrm{~cm}(\cong 16 \mathrm{in})$. This work aims to evaluate the physical and chemical properties as well as the morphological classification of four anthroposol profiles surveyed in the urban area of the municipality of Guarapari - Espírito Santo. The anthroposols that were examined showed heterogeneous characteristics, which indicates material variability in their formation. Profiles 1, 3 and 4 present specific chemical disruptions between horizons and natural strata, regarding layers formed by anthropogenic action, such as deposited and pedological waste. As for the chemical and morphological features analyzed, it was possible to rate three different suborders (Somic, Decapitic and Lixico), three major groups (Áquico, Camadic and Parcialic) and two subgroups (Aluminic and Eutrophic). Therefore, the profiles were classified as: Anthrosol Sômico Camádico Eutrófico (Eutrophics), Anthrosol Decapítico Parciálico Alumínico and two Anthrosols Líxicos Áquicos Eutróficos.

Keywords: Anthropogenic Environment; Anthropic Action; Morphological Description. 


\section{Introdução}

O ambiente urbanizado propicia a ocorrência de uma integração entre elementos antrópicos e naturais resultando dentre outros aspectos, na formação de antropossolos nessa configuração urbana de paisagem integrada (PELOGGIA, 2017). A paisagem integrada ao qual os antropossolos fazem parte é designada por Bolós (1981) como sendo constituída por elementos sociais e naturais, havendo possibilidade de construção de uma diversidade de ambientes antropizados, como Peloggia (1998), Pedron et al. (2004), Curcio et al. (2004) evidenciam na dinâmica sócio natural dos ambientes antropogênicos (relevo e solos), formados no Antropoceno, anteriormente designado como Tecnógeno (TER STEPANIAN, 1988).

Segundo Bólos (1981), a paisagem integrada é composta de elementos naturais e sociais, sendo formada por uma gama de relações. Portanto, a paisagem estabelece relações dinâmicas entre componentes antrópicos, físicos e biológicos. Essa possibilidade de transformação inclui a sociedade como agente de alteração destas paisagens integradas (BÓLOS, 1981), sendo o antropossolo ou solo antropogênico um componente resultante da ação antrópica, formado a partir da alteração das diferentes dinâmicas dos componentes de uma paisagem qualquer em sua interação com a sociedade.

A formação do solo na paisagem, advinda da proposta apresentada por Jenny (1941), é resultante da interação dos seguintes fatores: clima, material de origem, organismos, relevo e tempo cronológico. É importante ressaltar que essa "visão clássica" de formação do solo (DAGNINO, 2005) é voltada para solos naturais, com pouca ou nenhuma interferência antrópica.

Quanto à ação antrópica nos solos, Jenny (1941) reconhecia que o homem é um agente pedogenético, fundamental em duas condições: eliminando a cobertura vegetal natural e consequentemente alterando as características do clima e do solo, a partir da implementação de práticas agrícolas que alteram as características químicas, físicas e morfológicas dos solos que estão em interação na paisagem.

Dagnino (2005) destaca que os cinco fatores de formação integram a base dessa "visão clássica" de formação dos solos, que insere a sociedade e as suas técnicas como parte integrante do fator "organismos". Essa visão clássica para os solos naturais é correta, porém o seu uso para os solos antropogênicos torna-se incompleta. Além dos cinco fatores de formação dos solos, soma-se a ação antrópica, que transforma o solo em um "corpo artificial" (MACHADO, 2012).

Com relação à influência antrópica no solo, a $5^{\text {a }}$ edição do Sistema Brasileiro de Classificação de Solos SiBCS - (EMBRAPA, 2018) atribui o termo "antrópico" como pertencente ao conceito de "extraordinário", presente no $4^{\circ}, 5^{\circ}$ e $6^{\circ}$ nível categórico, contendo quatro classes de solos com este termo, a saber: i) Latossolos Amarelos Distrocoesos antrópicos, ii) Latossolos Amarelos Distróficos antrópicos, iii) Argissolos Amarelos Distróficos plintossólicos antrópicos e iv) Argissolos Vermelhos Eutróficos abrúpticos latossólicos antrópicos.

A proposta de classificação de Curcio et al. (2004), voltado à definição, caracterização e classificação de antropossolos, que é a classe de maior expansão no mundo (DIAS, 2017), apresenta uma definição mais congruente de antropossolo, a qual se torna o conceito utilizado nesta pesquisa. Este conceito indica que são solos que possuem $40 \mathrm{~cm}$ ou mais de espessura, compostos por uma ou mais camadas antrópicas com material inorgânico e/ou orgânico formado exclusivamente pela ação antrópica (CURCIO et al., 2004).

Dessa forma, o presente artigo tem como objetivo levantar e diagnosticar informações geográficas (químicas, físicas e morfológicas) para a caracterização e classificação dos antropossolos, a fim de aplicar a proposta de Curcio et al. (2004), e compreender aspectos relacionados a formação desses solos na periferia da área urbana do município de Guarapari-ES.

\section{Materiais e métodos}

\section{1. Área de Pesquisa}

O município de Guarapari, localizado na porção sul do Estado do Espírito Santo (Figura 1) possui população estimada em 126.701 habitantes (IBGE, 2020). Na cidade ocorreu um crescimento rápido do total populacional, com aumento de 64.982 habitantes entre os anos 1991-2020 (GIRARDI; COMETTI, 2006; IBGE, 2020) e consequentemente o aumento da área urbana em aproximadamente $3,744 \mathrm{~km}^{2} \mathrm{em} 16$ anos como constatou (BARRETO NETO et al. 2011), causando alteração do relevo e de solos pela atividade humana.

A presente pesquisa segue uma sequência de procedimentos modificados a partir da base proposta por Gomes et al. (2012), como o levantamento bibliográfico, trabalho de campo com levantamento das 
informações dos ambientes e da utilização de manuais amplamente utilizados nos trabalhos que envolvem a descrição e coleta de solos, como Santos et al. (2015) e a proposta de classificação morfológica de antropossolos realizada por Curcio et al. (2004). As modificações dos procedimentos realizadas são a partir das análises laboratoriais referentes aos aspectos morfológicos, químicos e físicos dos antropossolos.

A primeira etapa foi o trabalho de campo, com viés de reconhecimento das áreas e da localização dos antropossolos (Figura 1), demarcadas por GPS (Garmin Map 64), observando os usos e as modificações antrópicas e a espacialização dos antropossolos. A partir do trabalho de campo observou-se que na área periférica, de expansão urbana, é onde os antropossolos estavam mais presentes e possuíam melhor acesso. Concluiu-se que sobre os mangues e loteamentos ou nivelamento do terreno é onde havia maior número de formações destes solos. Assim, foram selecionados e coletados quatro perfis: três em aterros sobre mangue e um em construção de pista de motocross (decapitação do solo/relevo).

Durante a coleta e descrição morfológica, foram levantados os seguintes dados de descrição: textura (SANTOS et al., 2015), profundidade e transição dos horizontes e camadas, presença de água, presença de raízes, características do ambiente, presença de modificações e tipos de materiais antrópicos presentes nos perfis (CURCIO et al., 2004; SANTOS et al., 2015).

As amostras das camadas de cada antropossolo foram secas ao ar, passadas em peneiras de 2,00 mm (TFSA) e levadas para o laboratório de rotina, onde foram realizadas análises químicas e físicas de acordo com o manual da EMBRAPA (2017).

As análises químicas selecionadas foram de acordo com a EMBRAPA (2017): o pH (água) por meio de eletrodo combinado imerso em suspensão solo:líquido (água), 1:2,5; Capacidade de Troca de Cátions potencial $(\mathrm{T}=\mathrm{K}+\mathrm{Ca}+\mathrm{Mg}+[\mathrm{H}+\mathrm{Al}])$ e efetiva $(\mathrm{t}=\mathrm{K}+\mathrm{Ca}+\mathrm{Mg}+\mathrm{Al})$; Percentagem de Saturação de Bases $(\mathrm{V} \%=[\mathrm{SB} \times 100] / \mathrm{T}$, onde $\mathrm{SB}=\mathrm{K}+\mathrm{Ca}+\mathrm{Mg}+[\mathrm{Na}])$; Percentagem de Saturação por Alumínio $(\mathrm{m} \%=$ [100 x Al $\left.{ }^{3}\right] / \mathrm{t}$ ), Índice de Saturação por Sódio (ISNa\% = $100 \times \mathrm{Na}^{+} / \mathrm{T}$ ), macronutrientes $(\mathrm{Ca}, \mathrm{Mg}, \mathrm{P}, \mathrm{K}$ e S) e micronutrientes (Fe, Mn e $\mathrm{Zn}$ ) do solo.

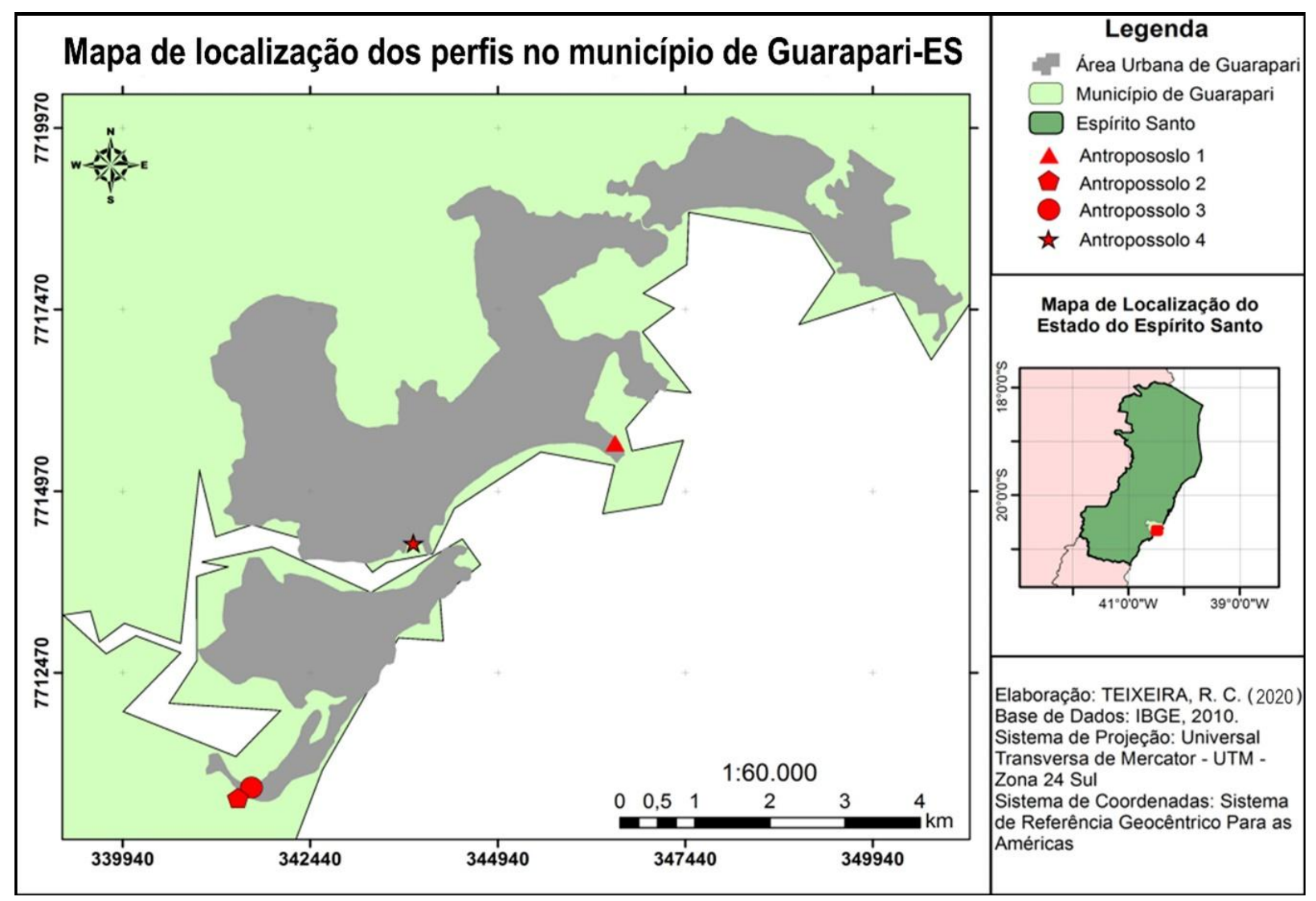

Figura 1: Localização do Município de Guarapari - ES e dos quatro Antropossolos analisados.

A análise física de granulometria (argila, silte e areia) foi selecionada para realizar a classificação textural dos antropossolos, tendo sido necessária a remoção da matéria orgânica com água oxigenada $\left(\mathrm{H}_{2} \mathrm{O}_{2}\right)$ nos solos com muita matéria orgânica (perfis 3 e 4) e a dispersão com solução de hidróxido de sódio $(\mathrm{NaOH}) 1$ mol L ${ }^{-1}$ (DONAGEMMA et al., 2017). Para o resultado das análises física e químicas foram realizados os 
cálculos estatísticos de média, desvio padrão (DP) e coeficiente de variação (CV) a fim de determinar a variabilidade da composição química e física entre as camadas de cada antropossolo (ROGERSON, 2012).

Para a realização da classificação dos antropossolos, a nomenclatura utilizada foi a proposta elaborada por Curcio et al. (2004), a qual tem a seguinte hierarquia de classificação: ordem - subordem - grandes grupos subgrupos. A classificação das subordens e grandes grupos foi realizada em campo, enquanto os subgrupos foram classificados a partir de análises químicas, com exceção aos subgrupos Homogênico, Heterogênico e Saprolítico, que são passiveis de classificação durante a coleta e descrição morfológica.

\subsection{Classificação de Antropossolos}

A proposta de classificação realizada por Curcio et al. (2004), voltada para a classificação de antropossolos, separa as intervenções ou ações antrópicas na formação destes pedons, segundo os autores, em três principais ações:

I) Adição - incremento de materiais sobre os solos, saprolitos, regolitos e/ou rochas;

II) Decapitação - retirada parcial ou total de solos e/ou saprolitos, regolitos e rochas;

III) Mobilização - movimentação/mistura parcial ou total de horizontes/solos.

Para realização da classificação das subordens (segundo nível), dos grandes grupos (terceiro nível) e de partes dos subgrupos (quarto nível) é necessário o reconhecimento das características morfológicas. Enquanto para maior parte dos subgrupos é necessária à realização de análises laboratoriais de caráter químico e/ou biológicos, quando necessário. No caso, foram utilizadas as análises laboratoriais de caráter químico, tais como V\%, m\% e ISNa, por exemplo.

\section{Resultados e Discussões}

\subsection{Perfil 1: Antropossolo Sômico Camádico Eutrófico}

O perfil 1 (Figura 2), localizado próximo à Praia da Cerca (Figura 1), é formado majoritariamente por granulometria arenosa (Tabela 1) derivado de deposição holocênica marinha, que foi coberta por adição antrópica (camadas 1.1 e 1.2), com materiais alóctones de características discrepantes ao local receptor, contendo maior quantidade de argila. A camada 1.1 foi classificada como "franco-argilo-arenoso" e a camada 1.2 foi classificada como "argila". Enquanto as camadas sedimentares mais profundas (camadas 1.3, $1.4,1.5,1.6$ e 1.7), de formação natural, foram classificadas como arenosas.

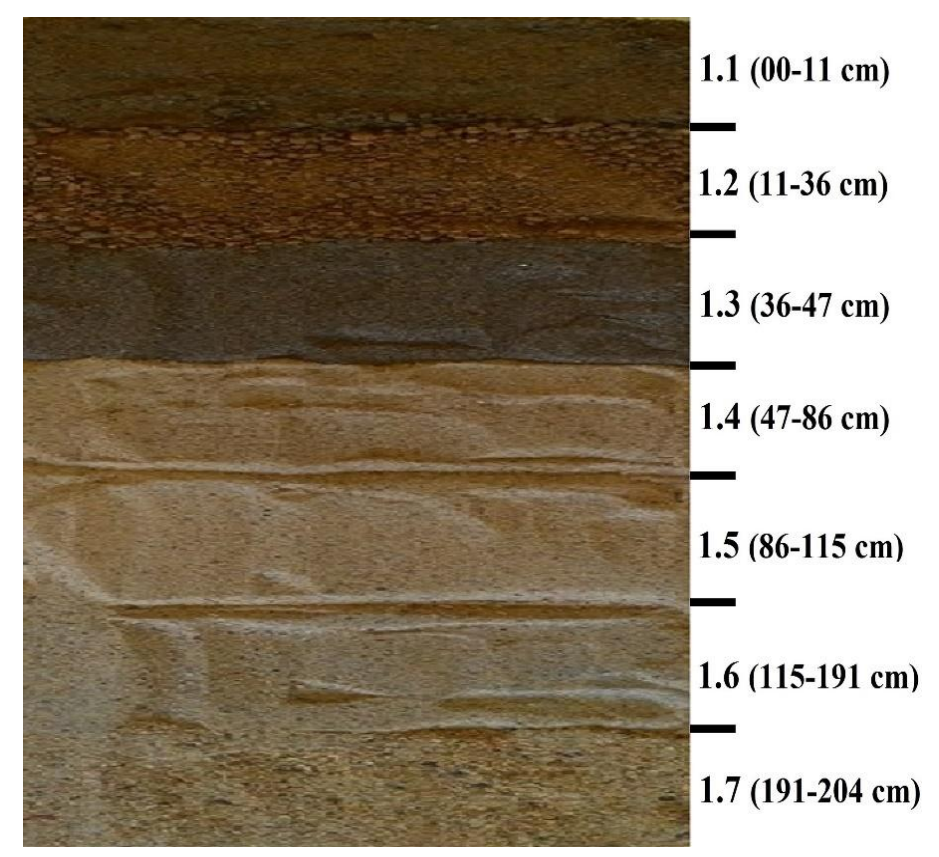

Figura 2: Perfil 1 - Antropossolo Sômico Camádico Eutrófico, esquema de perfil montado a partir de amostras das camadas coletadas em campo. 
A observações morfológicas e granulométricas indicam que este antropossolo possui dois momentos de formação. Sendo o primeiro momento advindo de um processo natural, com a deposição sedimentar holocênica e desenvolvimento do horizonte A e consequentemente de vegetação e incorporação de material orgânico. No segundo momento, houve a adição de materiais alóctones a área, enterrando o horizonte A natural $(41-51 \mathrm{~cm})$. Com o decorrer do tempo e desenvolvimento da vegetação um novo horizonte $\mathrm{A}$ tende a ser formado. A transição entre os horizontes em todo perfil foi classificada clara e plana, portanto, de fácil percepção visual e mais precisa.

Os resultados das análises químicas e física estão na Tabela 1. Observa-se nos resultados químicos que existe uma descontinuidade de alguns valores ( $\mathrm{P}, \mathrm{Fe}, \mathrm{Zn}$ e V\%) entre as camadas antrópicas (1.1 e 1.2), indicados pelo CV e DP. Quanto às camadas naturais e antrópicas também há descontinuidade dos valores químicos, sendo os valores de fertilidade maiores para as camadas adicionadas em comparação com os horizontes, naturais $(1.4,1.5,1.6$ e 1.7). Entre essas camadas também ocorre descontinuidade nos valores da granulometria. As camadas antrópicas $(1.1$ e 1.2) possuem granulometria argilosa em contraposição às camadas naturais, mais arenosas.

Portanto, a caracterização química deste antropossolo é resultado da adição de materiais alóctones, resultando na subordem Sômico. Como a adição foi realizada em camadas, para os grandes grupos ficou caracterizado como Camádico. Para a caracterização do subgrupo, observa-se os dados químicos (Tabela 1), ao qual foi constatada alto valor de V\%, com média de 94\%, advindo do material adicionado. Desta forma, o subgrupo é classificado como sendo Eutrófico.

A presença de descontinuidade é destacada nos dados estatísticos de CV e de DP (Tabela 1), ao qual se constatou, principalmente, descontinuidade para os valores de $\mathrm{P}(\mathrm{DP}=7,83)$, para o $\mathrm{K}(\mathrm{DP}=23,66)$, para $\mathrm{o}$ $\mathrm{Na}(\mathrm{DP}=23,91)$ e para $\mathrm{Fe}(\mathrm{DP}=7,41)$.

Tabela 1: Propriedades químicas e físicas das camadas do Perfil 1.

\begin{tabular}{|c|c|c|c|c|c|c|c|c|c|c|c|}
\hline \multirow{2}{*}{ Camada } & pH & $\mathbf{P}$ & $\mathrm{K}$ & $\mathrm{Na}$ & $\mathrm{Ca}$ & Mg & Al & $\mathrm{H}+\mathrm{Al}$ & SB & $\mathbf{t}$ & $\mathbf{T}$ \\
\hline & $\mathrm{H}_{2} \mathrm{O}$ & \multicolumn{3}{|c|}{$\mathrm{mg} \mathrm{dm}^{-3}$} & \multicolumn{7}{|c|}{ cmolc $\mathrm{dm}^{-3}$} \\
\hline $\mathbf{1}(00-11 \mathrm{~cm})$ & 5,10 & 21,90 & 70,00 & 199,80 & $\begin{array}{ll}30 & 6,1\end{array}$ & $19 \quad 0,65$ & 90,00 & 0,00 & 7,93 & 7,93 & 7,93 \\
\hline $2(1$ & 5,18 & 4,40 & 11,00 & 126,70 & $\begin{array}{ll}70 & 5,3\end{array}$ & $36 \quad 0,56$ & $6 \quad 0,00$ & 20 & 6,50 & 6,50 & 6,70 \\
\hline $3(41$ & 5,39 & 28,40 & 9,00 & 140,70 & $70 \quad 5,2$ & $25 \quad 0,42$ & $2 \quad 0,00$ &, 80 & 6,30 & 6,30 & 8,10 \\
\hline $4(51-86 \mathrm{~cm})$ & 5,21 & 17,20 & 7,00 & 143,70 & $\begin{array}{ll}70 & 2,8\end{array}$ & $33 \quad 0,25$ & $5 \quad 0,00$ & 0,20 & 3,72 & 3,72 & 3,92 \\
\hline $.5(8$ & 5,28 & 19,60 & 4,00 & 141,70 & $\begin{array}{ll}70 & 2,3\end{array}$ & $32 \quad 0,1 c$ & $9 \quad 0,00$ & 0,20 & 3,14 & 3,14 & 3,34 \\
\hline $.6(1$ & 6,00 & 17,90 & 8,00 & 134,70 & $70 \quad 2,1$ & $19 \quad 0,16$ & $6 \quad 0,00$ & 0,00 & 2,96 & 2,96 & 2,96 \\
\hline $7(19$ & 5,23 & 10,10 & 7,00 & 145,70 & $70 \quad 2,4$ & $10 \quad 0,2$ & $4 \quad 0,00$ & 0,20 & 3,29 & 3,29 & 3,49 \\
\hline Iédia & 5,34 & 17,07 & 16,57 & 147,5 & $57 \quad 3,7$ & $79 \quad 0,36$ & $6 \quad 0,00$ & 0,37 & 4,83 & 4,83 & 5,21 \\
\hline 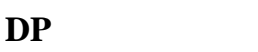 & 0 & 7,83 & 23,66 & 23,91 & $\begin{array}{ll}1 & 1,7\end{array}$ & $73 \quad 0,20$ & $0 \quad 0,00$ & 0,64 & 2,02 & 2,02 & 2,28 \\
\hline & 006 & 0,46 & 143 & 0,16 & 0,4 & $16 \quad 0,57$ & $7 \quad 0,00$ & 1,71 & 0,42 & 0,41 & 0,44 \\
\hline \multirow{3}{*}{ Camada } & & \multirow[t]{2}{*}{-1} & \multirow{2}{*}{ ISNa } & \multirow{2}{*}{$\mathbf{F}$} & \multirow{2}{*}{ Mn } & \multirow{2}{*}{$\mathrm{Zn}$} & \multicolumn{2}{|c|}{ Areia } & & 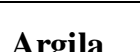 & \multirow{3}{*}{$\begin{array}{c}\text { Classe } \\
\text { Textural }\end{array}$} \\
\hline & & & & & & & ssa & Fina & & & \\
\hline & & $\%$ & & \multicolumn{3}{|c|}{$\mathrm{mg} \mathrm{dm}^{-3}$} & \multicolumn{4}{|c|}{$\mathrm{kg} \mathrm{kg}^{-1}$} & \\
\hline $.1(00-11 \mathrm{~cm})$ & 100,00 & 0,00 & 10,95 & 9,20 & 15,7 & 1,79 & 0,326 & 0,364 & 0,066 & 0,245 & $\begin{array}{c}\text { Franco } \\
\text { Argilo } \\
\text { Arenoso }\end{array}$ \\
\hline 2( & 97,00 & 0,00 & 8,22 & 23,6 & 9,00 & 0,60 & 0,295 & 0,205 & 0,072 & 0,428 & Argila \\
\hline $3(3$ & 77,80 & 0,00 & 7,55 & 2,30 & 7,60 & 0,21 & 0,102 & 0,824 & 0,015 & 0,058 & Areia \\
\hline $1.4(47-86 \mathrm{~cm})$ & 94,90 & 0,00 & 15,94 & 2,80 & 6,40 & 0,11 & 0,293 & 0,655 & 0,016 & 0,036 & Areia \\
\hline $1.5(86$ & 94,00 & 0,00 & 18,45 & 5,00 & 6,00 & 0,15 & 0,107 & 0,851 & 0,004 & 0,037 & Areia \\
\hline & 100,00 & 0,00 & 19,79 & 7,70 & 6,30 & 0,90 & 0,371 & 0,592 & 0,004 & 0,033 & Areia \\
\hline $1.7(191-$ & 94,30 & 0,00 & 18,15 & 4,00 & 6,30 & 0,09 & 0,496 & 0,450 & 0,024 & 0,029 & Areia \\
\hline Média & 94,00 & 0,00 & 14,15 & 7,80 & 8,18 & 0,55 & 0,28 & 0,56 & 0,03 & 0,12 & \\
\hline 1 & 7,57 & 0,00 & 5,14 & 7,41 & 3,48 & 0,62 & 0,14 & 0,24 & 0,03 & 0,15 & \\
\hline $\mathrm{CV}$ & 0,08 & 0,00 & 0,36 & 0,95 & 0,42 & 1,14 & 0,49 & 0,42 & 0,99 & 1,25 & \\
\hline
\end{tabular}

A partir da coleta e descrição morfológica em campo e análise das características físicas e químicas, este perfil foi classificado como Antropossolo Sômico Camádico Eutrófico. 


\subsection{Perfil 2: Antropossolo Decapítico Parciálico Alumínico}

O perfil 2 (Figuras 3 e 4), localizado em uma pista abandonada de motocross, próximo à comunidade do Bico do Urubu, passou por processo de ação de decapitação dos horizontes superficiais provenientes de LATOSSOLO AMARELO Distrocoeso típico (CUNHA et al., 2016). Portanto, neste perfil foi adotado o termo horizonte, ao invés de camada, pois há desenvolvimento pedogenético morfologicamente evidenciado, onde a transição entre os horizontes ocorre de forma difusa e plana, com definição da profundidade da transição menos precisa.

$\mathrm{Na}$ área do perfil coletado, como em grande proporção da área transformada, restam apenas partes dos horizontes B e BC (Figura 3). Os resultados das análises física e químicas estão expressos na Tabela 2, onde observa-se maior valor da quantidade de $\mathrm{Fe}$ no horizonte Bw1, decorrente da presença de concreção ferruginosa neste horizonte.

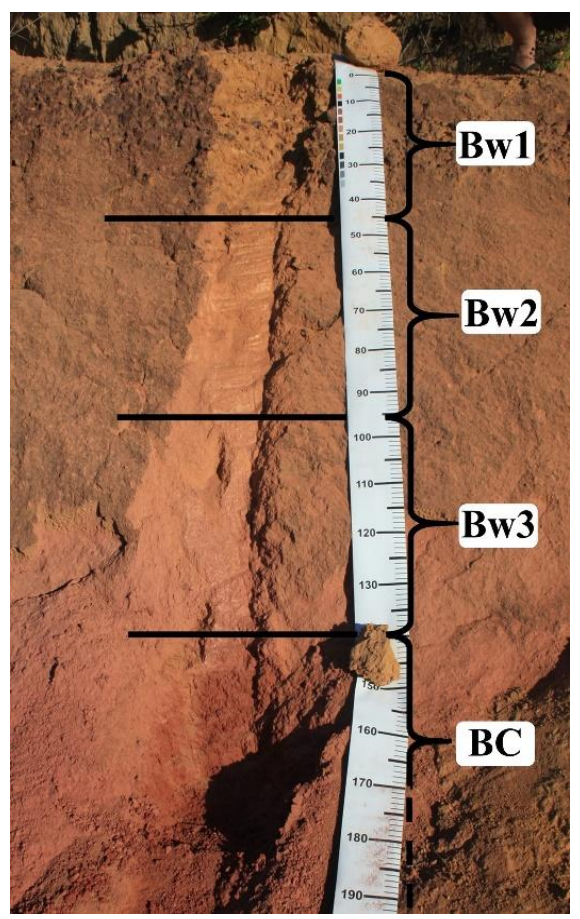

Figura 3: Perfil 2 - Antropossolo Decapítico Parciálico Alumínico, onde ocorreu decapitação e exposição dos horizontes B e C.

Quanto aos dados estatísticos (Tabela 2), não houve mudança abrupta ou descontinuidade entre os horizontes em relação aos valores físico e químicos, pois neste perfil não ocorreu a formação de camadas antrópicas.

Dessa forma, os maiores valores de DP constatados foram para o índice m\% $(15,17 \%)$ e K $(15,80 \%)$, sendo a variação entre os horizontes derivado de processo natural, pois neste antropossolo não houve a adição de materiais antrópicos.

A partir da ação de retirada das camadas superficiais, a subordem do antropossolo é classificada como Decapítico. Como somente uma parte do solo foi removido, sobrando partes dos horizontes Bw e do horizonte BC por inteiro (Figura 3), a denominação para os grandes grupos ficou caraterizada como Parciálico.

Para os subgrupos, a denominação foi distrófico, tendo para V\% média de $28 \%$ para os quatro horizontes e maior valor no horizonte Bw1 (35,2\%). Em relação inversa a V\%, os valores encontrados para m\% foram altos em relação aos outros três antropossolos, tendo somente o horizonte em contato com a superfície (Bw1) valor de $\mathrm{m}$ igual a 20,80\% (abaixo de 50\%). Os três horizontes mais profundos do perfil possuem média de $51,1 \%$. Assim, para os subgrupos a classificação é Alumínico, devido à predominância do caráter Alumínico em $3 / 4$ das camadas. Essa alta quantidade de $\mathrm{Al}$ se deve dentre outros aspectos a alta concentração de caulinita no material desenvolvido sobre tabuleiro costeiro, responsável pelo controle do equilíbrio químico do alumínio no solo (MOREAU et al., 2006; ROCHA, 2016).

A partir da coleta e descrição morfológica em campo e análise das características físicas e químicas, este perfil é classificado como Antropossolo Decapítico Parciálico Alumínico. 
Tabela 2: Propriedades Físicas e Químicas dos horizontes do Perfil 2.

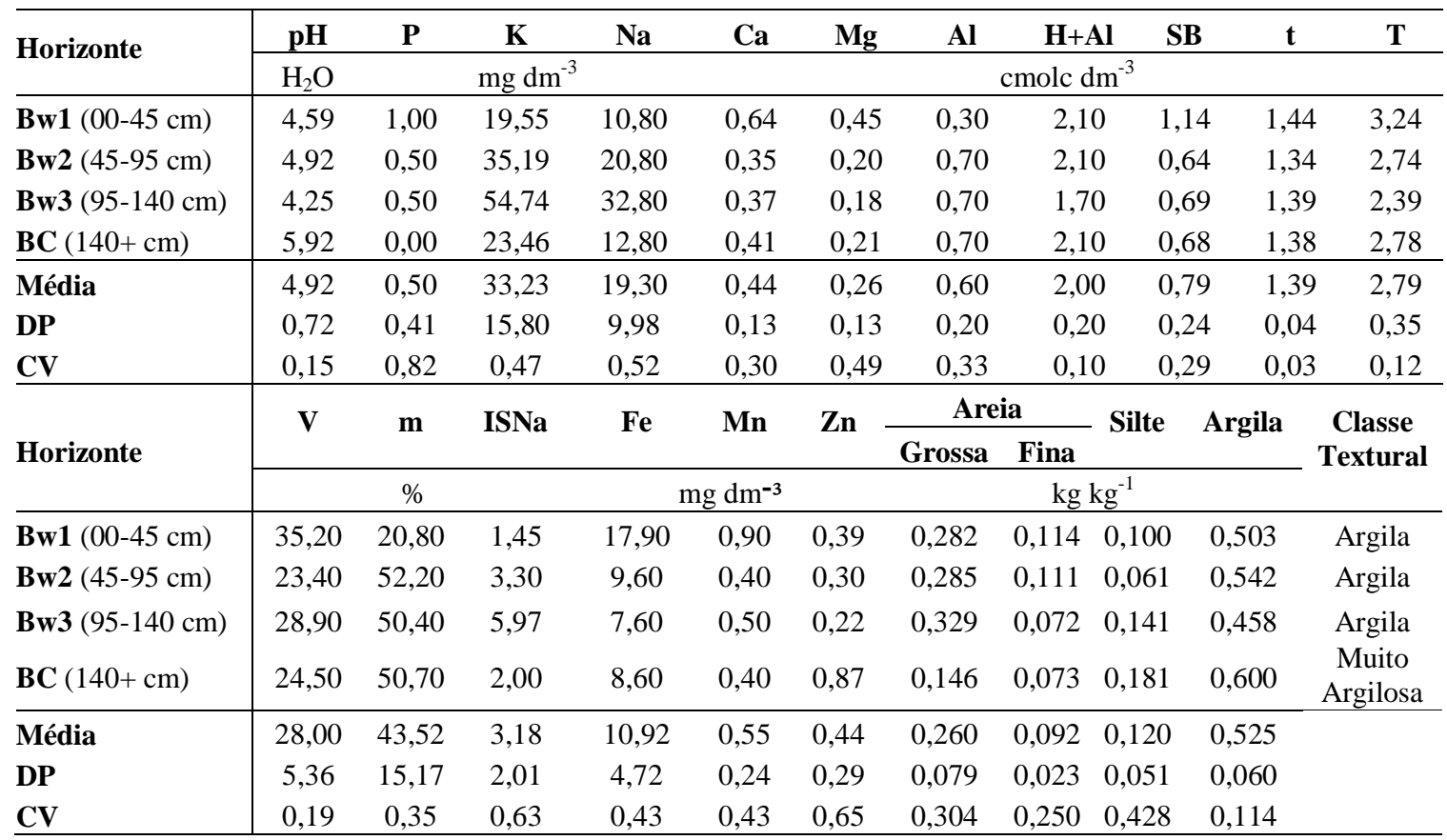

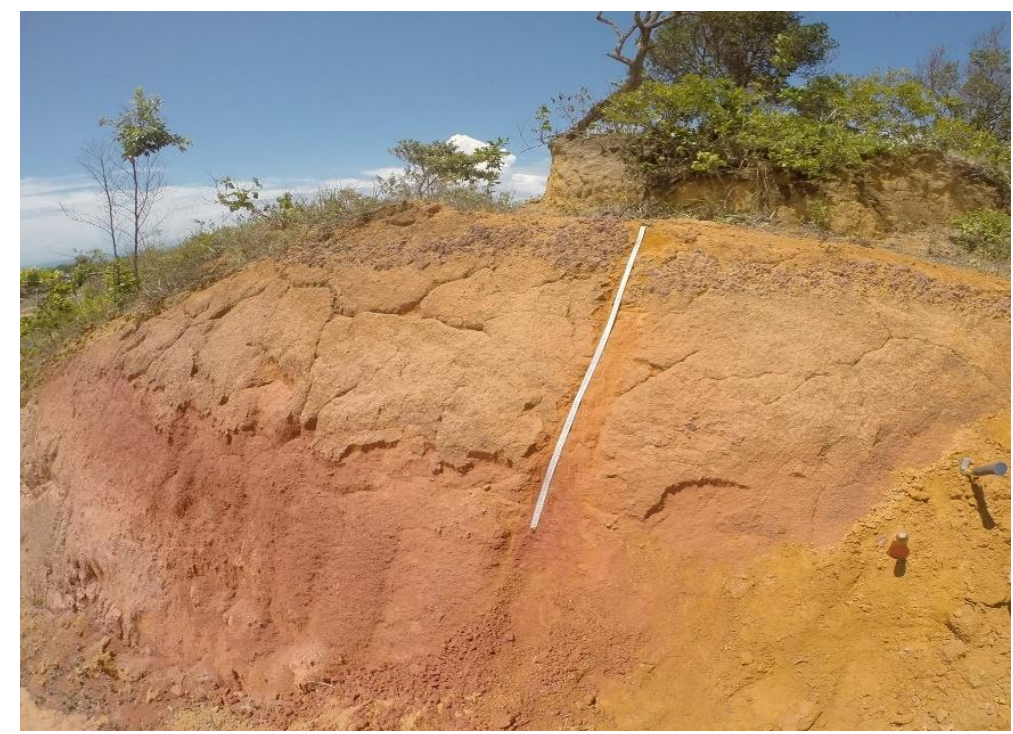

Figura 4: Ambiente do perfil 2, que apresenta remoção da vegetação e de partes do solo com exposição dos horizontes B e C para a construção de uma pista de motocross em Guarapari-ES.

\subsection{Perfil 3: Antropossolo Líxico Áquico Eutrófico}

O perfil 3 (Figuras 5 e 6) está localizado nas proximidades da comunidade Bico do Urubu (Figura 1), em ambiente com deposição de lixo misturado a solos e restos de construções. É composto de diversos materiais: mineral (solo e concreto), orgânico (ossos e restos de vegetação) e artefatos humanos (porcelana, plástico e vidro). Essa área apresenta-se como um aterro sobreposto a um manguezal, voltado atualmente para fins de loteamento (Figura 6).

Constatou-se, durante a descrição do perfil, que este antropossolo sofreu duas ações distintas, sendo a ação de adição e a de mobilização das camadas adicionadas, tendo ocasionado a mistura de material antrópico, mineral e orgânico. A subdivisão do perfil em camadas foi necessária devido a formação deste perfil ser, em geral, de camadas sobrepostas irregularmente. Assim, a transição entre as camadas se classifica como abrupta e também como em irregular, onde foi necessário indicar uma profundidade "média" entre as transições, de forma menos precisa. 


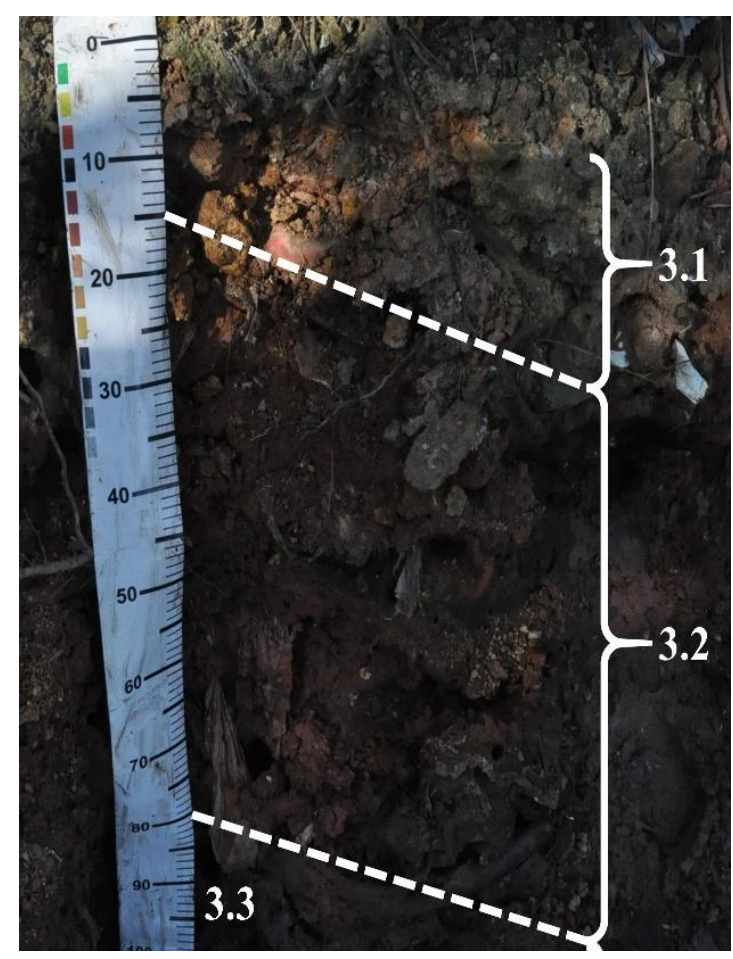

Figura 5: Perfil 3 - Antropossolo Líxico Áquico Eutrófico, localizado em um ambiente de lixão aterrado sobre um manguezal nas proximidades da comunidade "Bico do Urubu".

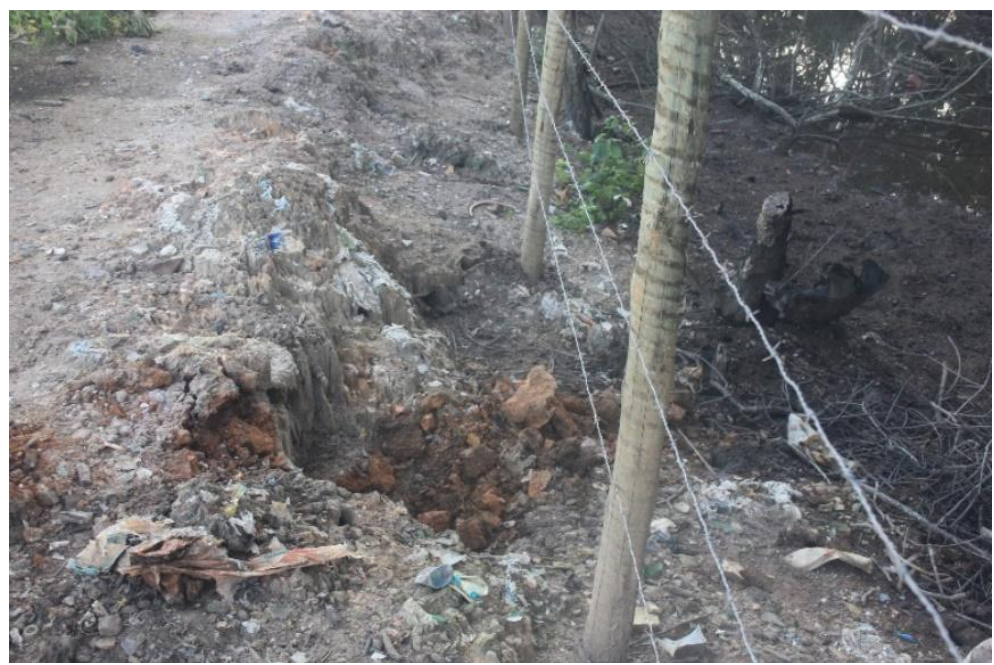

Figura 6: Ambiente de coleta do perfil 3 - antigo lixão e "bota-fora" que atualmente é um loteamento clandestino.

Os resultados das análises física e químicas referentes ao perfil 3 estão expressos na Tabela 3. Nela há também os resultados calculados pelas medidas de DP e CV (Tabela 3), aos quais indicam que este antropossolo foi o que apresentou a maior variabilidade química entre os quatro perfis estudados.

Este antropossolo é o que contém os maiores valores de DP, principalmente para o $\mathrm{Na}(1201,27)$ e o $\mathrm{Fe}$ $(418,94)$, elementos que apresentaram altos teores comum a um ambiente influenciado por maré, que além de conter maior quantidade de sais também gera um ambiente redutor, tornando o Fe mais móvel e livre no solo. Onde os valores de $\mathrm{Fe}$ e $\mathrm{Na}$ aumentaram com a profundidade das camadas, tendo maior influência de água salobra, apresentando aumento abrupto dos valores.

Com valores de DP menores que o $\mathrm{Na}$ e o $\mathrm{Fe}$, porém, ainda altos, outros elementos são destacados, como por exemplo, os valores de DP de P $(29,9), \mathrm{K}(35,92)$ e Zn $(37,0)$, evidenciando, portanto, descontinuidade química entre as camadas, assim como a variedade de materiais que compõem tal perfil. 
Tabela 3: Propriedades químicas e físicas das camadas do Perfil 3.

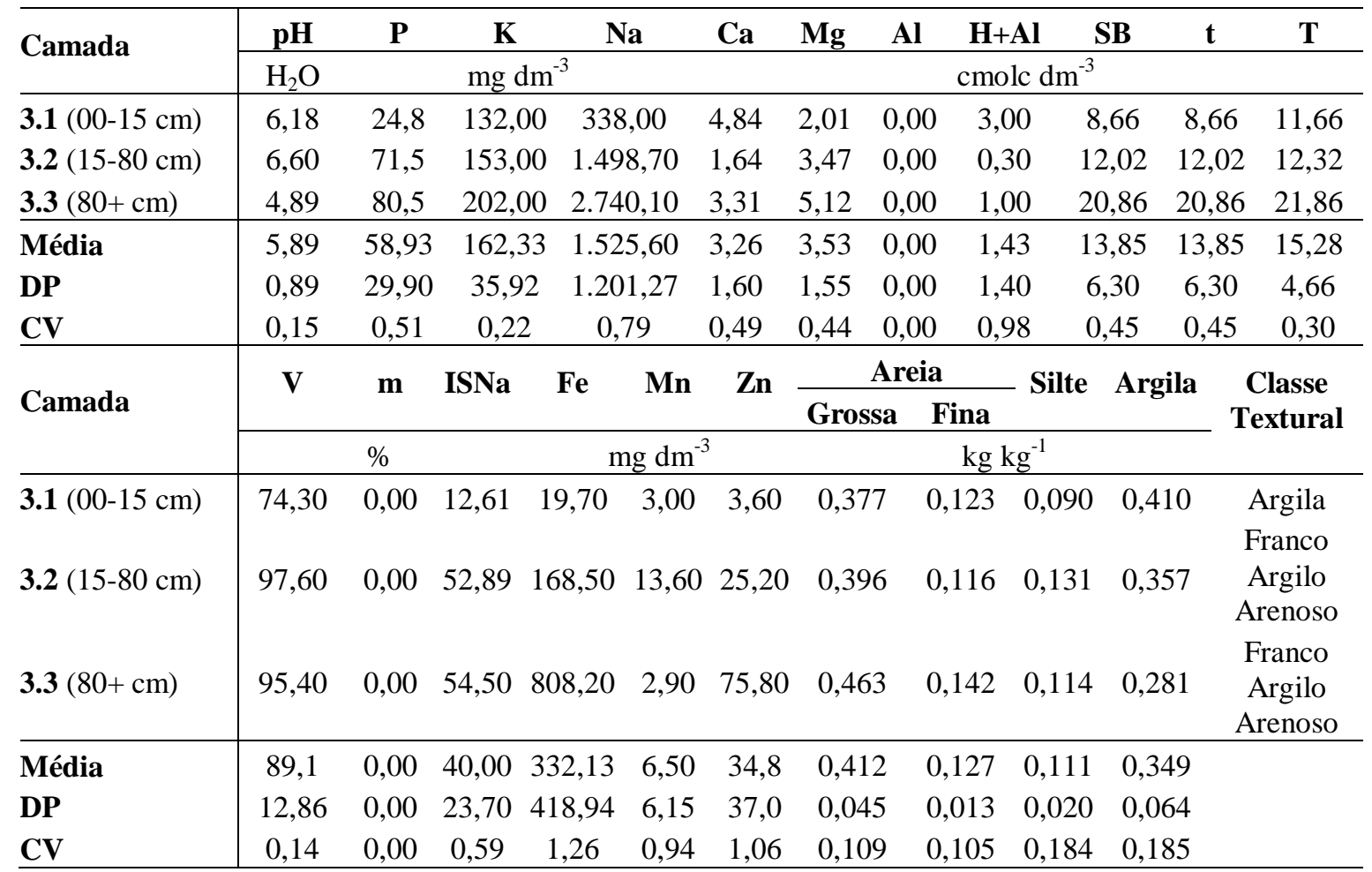

Devido à deposição de rejeitos antrópicos (lixos variados), a subordem do antropossolo é classificado como Líxico. Como se apresenta sobreposto a um manguezal, com periódica influência de saturação por água, caracteriza-se como sendo pertencente ao grande grupo Áquico. Para os subgrupos, a denominação correta é Eutrófico devido ao alto valor de V\%, com média de 89,1\% (Tabela 3) para todas as camadas.

A partir da coleta e descrição morfológica em campo e análise das características físicas e químicas, este perfil (Figura 5 e 6) é classificado como Antropossolo Líxico Áquico Eutrófico.

\subsection{Perfil 4: Antropossolo Líxico Áquico Eutrófico}

O perfil 4 (Figura 7), localizado no bairro Muquiçaba, caracteriza-se como sendo proveniente de depósitos de solo e de diversos artefatos antrópicos (tijolos, porcelanas, azulejos, plásticos, borracha, restos vegetais e tecidos) sobrepostos a um manguezal, onde recebe descarga de esgoto e de drenagem urbana por meio de bueiros (Figura 8). Onde a distinção entre as camadas foi realizada pela observação da textura, tipo de material antrópico presente e transição entre camadas, onde esta foi caracterizada como clara e ondulada, onde também foi necessário indicar uma profundidade "média" entre as transições, de forma menos precisa.

Os resultados das análises física e químicas deste antropossolo (Tabela 4) demonstram que assim como o do perfil 3, esse perfil apresentou alta variabilidade química entre as suas camadas. Os valores de DP mais representativos para este perfil são referentes ao $\mathrm{Na}(950,32)$ e $\mathrm{Fe}(607,02)$, que apresentaram mudança abrupta dos valores entre as suas três camadas. Onde a camada superficial apresenta alto valor de $\mathrm{Na}$ $(1972,80)$, o que indica que essa camada é proveniente de solo do manguezal.

Os componentes químicos $\mathrm{K}, \mathrm{P}$ e $\mathrm{Mn}$ e os índices $\mathrm{V} \%, \mathrm{~m} \%$, $\mathrm{T}$ e $\mathrm{t}$ também tiveram variação abrupta, podendo ser designadas como descontinuidade química. Quanto ao valor mais alto de $\mathrm{P}$ encontrado neste perfil, $124,90 \mathrm{mg} \mathrm{dm}^{-3}$ é representativo, porém menor do que os valores máximos encontrados em solos urbanos por Dias (2017) e Gabersek e Gosar (2018), 1096 e $3280 \mathrm{mg} \mathrm{dm}^{-3}$, respectivamente.

Em relação aos valores de $\mathrm{Na}, \mathrm{SB}$ e Fe, destaca-se a camada 4.2, que tem valores bem menores que as camadas 4.1 e 4.3 (Tabela 4), caracterizando descontinuidade química entre seus componentes e os índices citados. 


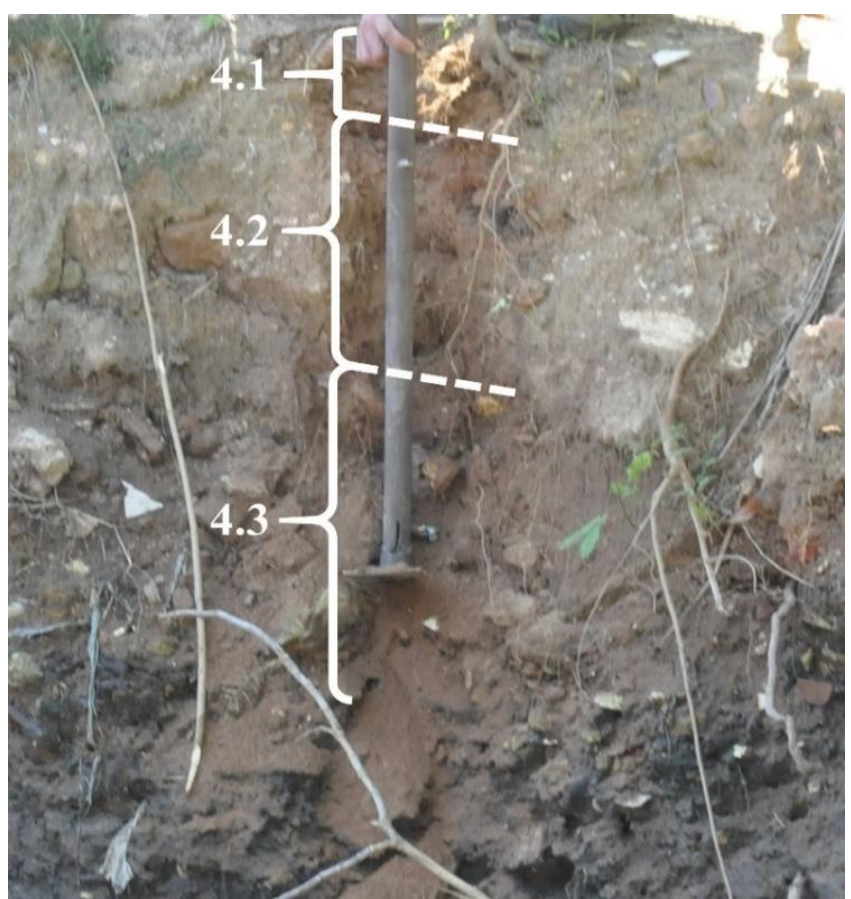

Figura 7: Perfil 4 - Antropossolo Líxico Áquico Eutrófico, localizado no bairro Muquiçaba. Fonte: os autores.

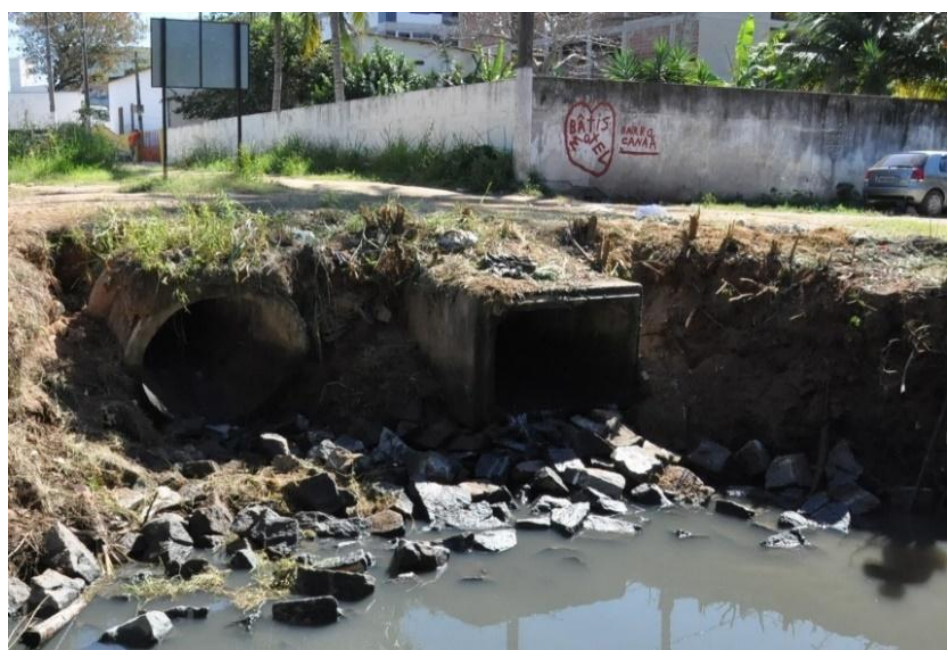

Figura 8: Ambiente do perfil 4, com influência de água da drenagem urbana, esgoto e periódica saturação por água salgada, com a formação do Antropossolo por adição de materiais alóctones.

Perante a classificação, a subordem deste antropossolo é o Líxico (detritos de construção e lixos domésticos). Assim como no perfil 3, ocorre periódica saturação por água, sendo assim, pertencente aos grandes grupos como a classe Áquico. Para o subgrupo, a denominação se faz como Eutrófico, por possuir média do valor de V\% igual $73,76 \%$. Onde possui uma alta heterogeneidade dos valores de V\%, tendo 46,4\% na camada 4.3 e de $100 \%$ na camada 4.2. Onde o perfil também apresenta descontinuidade química.

A partir das características morfológicas e químicas, este antropossolo é classificado como Antropossolo Líxico Áquico Eutrófico. 
Tabela 4: Propriedades químicas e físicas das camadas do Perfil 4.

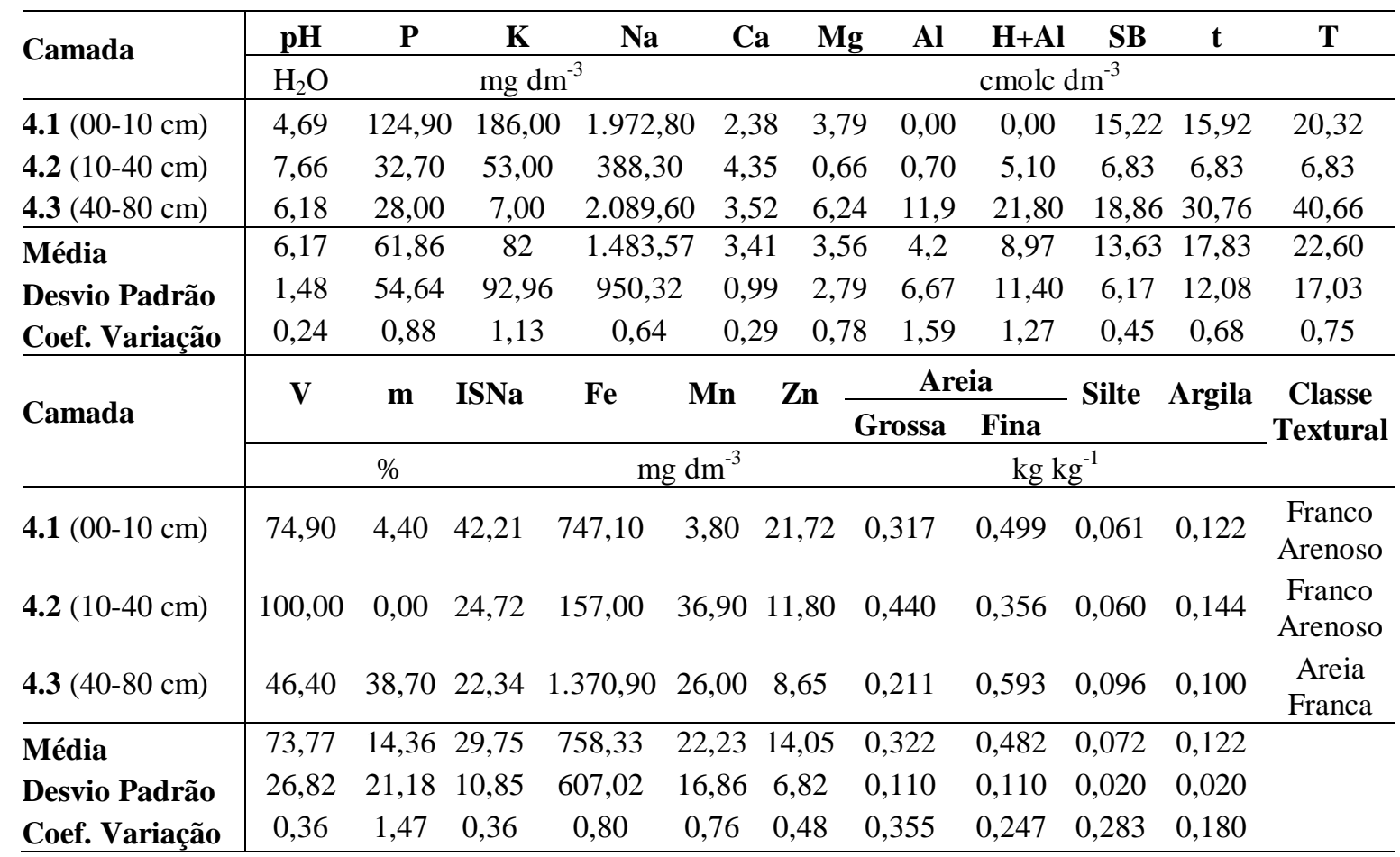

\subsection{Resultados Químicos dos Perfis}

Em relação aos constituintes químicos, Kämpf e Kern (2005) argumentam que o material pedológico é um indicador da ocupação e modificação humana em um determinado ambiente, pois os "solos são excelentes marcadores geoquímicos" e preservam ao longo do tempo diversas características resultantes da interação entre geoambientes e populações humanas no local onde estão vivendo.

Essa afirmação de Kämpf e Kern (2005), voltada para as Terras Pretas de Índio (arqueoantrossolos), se encaixa também em antropossolos formados em período de tempo recente, pois nestes também ocorrem várias modificações no aspecto químico quando advém da adição de materiais alóctones que possuem diferenças físicas e químicas comparado ao local receptor.

Quanto a composição química destes solos, em geral, a ação antrópica provoca alterações na química e fertilidade do solo dependendo do material adicionado. Podendo provocar alterações nos valores de diversos componentes químicos dos solos, entre os quais: $\mathrm{pH}, \mathrm{P}, \mathrm{Ca}, \mathrm{Mg}, \mathrm{Zn}$ e $\mathrm{Mn}$, provocando mudanças também nos valores de t, T, V\% e SB.

\subsubsection{Capacidade de Troca Catiônica e Soma de Bases Trocáveis}

Os valores de t, T e SB (Tabelas de 1 a 4), comparando os quatro antropossolos analisados, apresentamse com valores baixos somente nas camadas do perfil 2, confirmando as características observadas na coleta e descrição morfológica de campo, em razão da ausência de material que poderia provocar aumento dos referentes valores químicos. Além disso, esse antropossolo, por ser derivado de um solo com alto grau de intemperismo e lixiviação, tem baixa fertilidade como característica natural.

Isso ocorre no perfil 2 em função deste ser proveniente da decapitação de um solo natural, especificamente um pretérito LATOSSOLO AMARELO Distrocoeso típico (CUNHA et al., 2016). Para o perfil 1, observam-se valores de t, T e SB relativamente baixos em comparação aos perfis 3 e 4 . Em um esquema dos valores médios de t, T e SB das camadas de cada antropossolo, a sequência, em ordem crescente é:

Tabela 5: Valores médios em de t, T e SB em ordem crescente dos antropossolos coletados.

\begin{tabular}{lcccc}
\hline Perfil & $\mathbf{2}$ & $\mathbf{1}$ & $\mathbf{3}$ & $\mathbf{4}$ \\
\hline $\mathbf{t}$ & 1,39 & 4,83 & 13,85 & 17,83 \\
Perfil & $\mathbf{2}$ & $\mathbf{1}$ & $\mathbf{3}$ & $\mathbf{4}$ \\
$\mathbf{T}$ & 2,79 & 5,21 & 15,28 & 22,60 \\
Perfil & $\mathbf{2}$ & $\mathbf{1}$ & $\mathbf{4}$ & $\mathbf{3}$ \\
SB & 0,79 & 4,83 & 13,63 & 13,85 \\
\hline \multicolumn{4}{r}{}
\end{tabular}


Em solos ácidos a tendência é que o valor da capacidade de troca catiônica efetiva (t) seja inferior ao valor da capacidade de troca catiônica potencial (T), e é isso que se observa nos quatro perfis (Tabelas 1, 2, 3 e 4), com exceção ao valor de pH 7,66 na a camada 4.2 do perfil 4 (Tabela 4). Onde apresentaram valores de $\mathrm{pH}$ ácido e o valor de t menor que o de T, com exceção para as camadas 1.1 (perfil 1) e 4.2 (perfil 4).

No perfil 4 os valores de $\mathrm{T}$ e t (Tabela 4) possuem diferenças consideráveis devido aos valores do índice $\mathrm{m} \%$, onde entre os antropossolos com material adicionado (perfis 1, 3 e 4), o perfil 4 é o único que apresenta camadas com algum valor de índice $m \%$, com $4,40 \%$ na camada 4.1 e 38,70\% na camada 4.3.

\subsubsection{Percentagem de Saturação de Bases, Percentagem de Saturação por Alumínio e Índice de Saturação por Sódio}

Kämpf e Kern (2005) salientaram que os arqueoantrossolos possuem, em geral, altos valores de V\%. Consequentemente os valores de $\mathrm{m} \%$, dependendo do tipo de material adicionado ao solo, tendem a ter valores baixos. E isso pode ocorrer também em antropossolos recentes, dependendo do tipo de material acrescentado.

Em ambos os valores, V\% e m\%, Curcio et al. (2004) destacam que "as características químicas como saturação por bases e alumínio trocável são muito variáveis" entre as camadas. Assim, a variação dependerá das características naturais do material de origem e/ou do solo antecessor e/ou do tipo de constituintes adicionados. Essas variações são observadas nos perfis 1 e 4 (Tabelas 1 e 4), contendo as camadas dos antropossolos junto aos seus respectivos índices V\%, m\%, ISNa e os coeficientes de variação para cada índice.

Os índices de V\% e m\% indicam a classificação quanto aos subgrupos. Enquanto o índice ISNa foi considerado devido a característica da área estudada: ambiente litorâneo, que recebe influência das águas oceânicas, portanto, com altos valores de sódio. Onde o ISNa denota a "proporção de sódio solúvel em relação a capacidade de troca catiônica total do solo" (CAMPOS et al., 2017), possibilitando a classificação dos horizontes e perfis em relação ao caráter sódico ou solódico.

Observa-se nas tabelas que dos quatro antropossolos analisados, três são caracterizados como sendo eutróficos, exceto o perfil 2, onde estes valores altos de eutrofia foram mais elevados do que os encontrados por Dias (2017) e Costa e Peloggia (2019), que acharam valores máximos de V\% de 78\% e 76,68\%, respectivamente. Porém, em relação às camadas individuais de cada antropossolo eutrófico, o perfil 4 (Tabela 4) apresentou uma camada (4.3) com valor abaixo de 50\% (distrófico), demonstrando a possibilidade de ocorrer heterogeneidade interna a cada antropossolo nos valores de saturação por bases.

Para a m\% (Tabelas 1 a 4), houve grande diferença entre os perfis analisados, onde os perfis 1 e 3 apresentaram valor de $0 \%$ em todas as camadas. No perfil 2 os valores de $\mathrm{m} \%$ são relativamente altos, acima de 50\% nas três camadas mais profundas. Portanto, somente o perfil 2 apresentou o caráter alumínico.

O perfil 4 apresentou valores diferenciados do índice $\mathrm{m} \%$ entre as camadas, valor baixo na camada 4.1 ( 0 $10 \mathrm{~cm})$ com 4,40\%, valor nulo na camada $4.2(10-40 \mathrm{~cm})$ e $38,7 \%$ na camada $4.3(40-80 \mathrm{~cm})$. Os valores do perfil 4 estão distribuídos de forma descontínua, com coeficiente de variação igual a 21,2, possivelmente advinda de materiais heterogêneos depositados diferentemente para cada camada e a ocorrência de pedogênese incipiente (baixo grau de desenvolvimento pedogenético) no perfil.

Quanto ao ISNa (Tabelas 1 a 4) os valores de destaque foram para os perfis 3 e 4, como já esperado devido a posição de formação destes perfis em área de manguezal. O perfil 3 apresentou CV entre as três camadas igual a 23,7 e média de 53,69\% para as camadas 3.2 e 3.3. O perfil 4 apresentou destaque a camada 4.1, com valor de $42,21 \%$. Ambos estão em contato direto com águas marinhas em ambiente de manguezal, por isso os altos valores de ISNa.

\subsubsection{Macroelementos e Microelementos em Relação à Ação Humana}

As concentrações de elementos como $\mathrm{P}, \mathrm{Ca}, \mathrm{Zn}, \mathrm{Mn}$ e outros elementos podem ser interpretados como locais onde o "lixo" era depositado (SOKOLOFF; CARTER, 1952). Estes elementos são apontados por Kämpf e Kern (2005) como sendo propriedades que constituem "assinaturas antrópicas", que são derivados de materiais alóctones incorporados em maior quantidade ao ambiente devido pela ação antropogênica. 
Os elementos detectados e selecionados para os antropossolos 1, 3 e 4 como "assinaturas antrópicas" ou marcadores geoquímicos, quando ocorre adição de material alóctone, são os que apresentam valores altos, tal como: P, Ca, Zn e Mn. Além dos altos valores de K e Mg nos antropossolos 3 e 4 (Tabelas 3 e 4).

Nos três perfis de antropossolos que possuem acréscimo de material antropogênico, os elementos que se mostram em evidência são: $\mathrm{Ca}, \mathrm{P}, \mathrm{Mn}$ e $\mathrm{Zn}$. Nestes, os valores são advindos da diversidade de elementos adicionados ao antropossolo, tais como ossos, matéria orgânica, rejeitos de construções.

\section{Considerações finais}

O uso de análise morfológica do solo em campo voltada à classificação do mesmo, acoplada a dados de análise laboratorial química e física de rotina de solos foram relevantes para a pesquisa. Dessa forma, foi possível diagnosticar e compreender as propriedades morfológicas de cada perfil de antropossolo.

É necessário reforçar que, como ocorre em estudos de solos naturais, voltados à compreensão do desenvolvimento pedogenético e classificação morfológica dos mesmos, a perspectiva de analisar os perfis de antropossolos por meio da integração e soma de informações de dados laboratoriais e propriedades morfológicas possibilitou realizar uma compreensão mais ampla e concisa dos perfis. Conciliando assim, informações complementares entre as análises, gerando maior quantidade e qualidade de informações para a compreensão dos perfis.

Os dados químicos ratificam a influência da adição de material antropogênico no aumento de parâmetros químicos e na presença de descontinuidade química ao longo do perfil, destacando-se os altos valores de Saturação por Bases, resultando no enquadramento desses solos como eutróficos. Nestes casos, o aumento dos valores de Saturação por Bases é decorrente da adição de materiais de origem antrópica que possuem altos valores de bases em suas composições.

Destaca-se também a necessidade de incluir termos de propriedades especificas à medida que essas apareçam nas pesquisas, pois a proposta de classificação do antropossolos não as inseriu em sua base, tal como foi realizado na inserção do caráter sódico, baseado no SiBCS (EMBRAPA, 2018), ao qual os perfis 3 e 4 seriam classificados.

Dessa forma, os perfis de antropossolos analisados integram a base do ambiente urbano e suburbano do município de Guarapari - ES, ao qual demonstram as modificações realizadas pelo agente antropogênico das feições na planície litorânea nas proximidades das áreas urbanas, contendo considerável quantidade de fatores antropogênicos associados aos naturais que ocasionam na diversidade dos solos.

\section{Referências}

NETO, A.A.B.; MARCHESI, A.F.; LORENA, R. Mapeamento espaço-temporal da expansão urbana da Região Metropolitana da Grande Vitória no período de 1991 a 2009, no estado do Espírito Santo. In: XV Simpósio Brasileiro de Sensoriamento Remoto, Curitiba. Anais do XV Simpósio Brasileiro de Sensoriamento Remoto, 2011. 714-721.

BOLÓS, M.I.C. Problemática actual de los estudios de paisaje integrado. Revista de Geografia, Barcelona, v. 15, n. 1. 45-68, 1981.

BUNTING, B.T. Geografia do solo. Trad. NEWLANDS, T.S. Rio de Janeiro, Zahar, 1971.

CAMPOS, D.V.B.; TEIXEIRA, P.C.; PERES, D.V.; SALDANHA, M.F.C. Percentagem de saturação por sódio. In: TEIXEIRA, P.C.; DONAGEMMA, G.K.; FONTANA, A.; TEIXEIRA, W.G. (Orgs.). Manual de métodos de análise de solo. 3ed. Brasília: Embrapa; 2017. p. 247-248.

COSTA, J.R.; PELOGGIA, A.U. G. Geoquímica de Terrenos Urbanos Modificados pela Humanidade e Serviços Ecossistêmicos (SE): o Caso de Santa Maria (RS, Brasil). Revista do Departamento de Geografia, v. 37, 150-159, 2019.

CUNHA, A.M.; FEITOZA, H.N.; FEITOZA, L.R.; OLIVEIRA, F.S.; LANI, J.L.; CARDOSO, J.K.F.; TRINDADE, F.S. Atualização da legenda do mapa de reconhecimento de solos do Estado do Espírito Santo e implementação de interface no Geobases para uso de dados em SIG. Geografares, v.2, n.22, 32-65, 2016. DOI: https://doi.org/10.47456/geo.v\%25vi\%25i.30205 
CURSIO, G.R.; LIMA, V.C.; GIAROLA, N.F.B. Antropossolos: Proposta de Ordem (1 ${ }^{\text {a }}$ aproximação). Colombo: EMBRAPA Florestas, 2004.

DAGNINO, R.S. Antropossolo: A metamorfose do solo pela ação humana. Instituto de Geociências, UNICAMP, 2005. Disponível em: <http://pt.slideshare.net/ricardosdag/antropossolo-presentation>.

Dias, M.A. Antropossolos: enquadramento taxonômico e implicações ambientais. Dissertação (Mestrado em Geografia) - Universidade Federal do Paraná, Curitiba, 2017.

DONAGEMMA, G.K.; VIANA, J.H.M.; ALMEIDA, B.G.; RUIZ, H.A.; KLEIN, V.A.; DECHEN, S.C.F.; FERNANDES, R.B.A. Análise Granulométrica. In: TEIXEIRA, P.C.; DONAGEMMA, G.K.; FONTANA, A.; TEIXEIRA, W.G. (Orgs.). Manual de Métodos de Análise de Solo. 3.ed. Brasília: Embrapa; 2017.

EMBRAPA. Centro Nacional de Pesquisa de Solos. Manual de Métodos de Análise de Solo. 3.ed. Brasília: Embrapa, 2017.

EMBRAPA. Sistema Brasileiro de Classificação de Solos. 5a . ed. rev., ampl. EMBRAPA, Brasília, 2018.

Gabersek, M.; Gosar, M. Geochemistry of urban soil in the industrial town of Maribor, Slovenia. Journal of Geochemical Exploration, v. 187, 141-154, 2018. DOI: https://doi.org/10.1016/j.gexplo.2017.06.001

GIRARDI, G.; COMETTI, R.S. Dinâmica do uso e ocupação do solo no litoral sul do estado do Espírito Santo, Brasil. Revista Desenvolvimento e Meio Ambiente, n.13, 51-73, 2006. DOI: http://dx.doi.org/10.5380/dma.v13i0.3114

GOMES, T.C.; RIFFEL, E.S.; PITTELKOW, G.C.; PAUL, C.R. Caracterização e espacialização dos depósitos tecnogênicos no bairro Camobi: subsídio ao planejamento urbano do munícipio de Santa MariaRS. Revista Geonorte, Edição Especial, v.2, n.4, 276-288, 2012.

IBGE Cidades. Diretoria de Pesquisas, Coordenação de População e Indicadores Sociais. 2020. Disponível em: <https://cidades.ibge.gov.br/brasil/es/guarapari/panorama>.

JENNY, H. Factors of Soil Formation: A System of Quantitative Pedology. New York: McGraw-Hill, 1941. Kämpf, N.; Kern, D.C. O solo como registro da ocupação humana Pré-Histórica na Amazônia. In: Tópicos em Ciências do Solo. Viçosa, MG: Sociedade Brasileira de Ciência do Solo, vol.4, 277-320, 2005.

MACHADO, C.A. Gênese e Morfologia de Depósitos Tecnogênicos na Área Urbana de Araguaína (TO). Tese (Doutorado em Geografia) - Uberlândia: UFU, 2012.

MOREAU, A.M.S.S.; KER, J.C.; COSTA, L.M.; GOMES, F.H. Caracterização de solos de duas topossequências em tabuleiros costeiros do Sul da Bahia. Revista Brasileira de Ciência do Solo, v.30,10071019, 2006. DOI: https://doi.org/10.1590/S0100-06832006000600010

PEDRON, F.A; DALMOLIN, R.S.D; AZEVEDO, A.C; KAMINSKI, J. Solos Urbanos. Revista Ciência Rural, Santa Maria, v.34, n.5, 1647-1653, 2004.

PELOGGIA, A.U.G. O homem e o ambiente geológico: geologia, sociedade e ocupação urbana no município de São Paulo. São Paulo: Xamã, 1998.

PELOGGIA, A.U.G. O que produzimos sob nossos pés? Uma revisão comparativa dos conceitos fundamentais referentes a solos e terrenos antropogênicos. Revista UNG - Geociências, v.16, n.1, 102-127, 2017.

ROCHA, P.A. Solos do Manguezal da Baía de Guarapari - ES: mineralogia e fósforo como indicador de contaminação por esgoto doméstico. Tese (Doutorado em Solos e Nutrição de Plantas) - Viçosa: UFV, 2016.

ROGERSON, P.A. Métodos estatísticos para a geografia: um guia para o estudante. 7 ed. Porto Alegre: Bookman, 2012.

SANTOS, R.D.; SANTOS, H.G.; KER, J.C.; ANJOS, L.H.C.; SHIMIZU, S.H. Manual de descrição e 
coleta de solo no campo. 7 ed. Sociedade Brasileira de Ciência do Solo, Viçosa, 2015.

SOKOLOFF, V.P; CARTER, G.F. Time and trace metals in archaeological sites. Science, v.116, 1-5, 1952.

TER-STEPANIAN, G. The Beginning of Technogene. Bulletin of International Association of Enginnering Geology, Paris, n.38, 133-142, 1988.

(1) (9) (2) 